\title{
An Examination of the Use and Production of Space in Brian Friel's Translations (1980), Michel Tremblay's Solemn Mass for a Full Moon in Summer (2009) and Emma Donoghue's Room (2017)
}

\author{
Rania Khalil \\ Assistant Professor, Faculty of Arts \\ and Humanities, The British \\ University in Egypt.
}

\begin{abstract}
A play has various elements, many of which a skillful playwright can manipulate, the one constant element though in any written text or performance, is space. The analysis of space in drama is complex and revolves around what is visible to the audience and what is not. At the same time, space takes many forms whether architectural, metaphorical, virtual, psychological, geographical or theatrical. This paper analyses through Henri Lefebvre's theory
\end{abstract}

of space the use and production of space in three plays: Brian Friel's Translations (1980); Michel Tremblay's Solemn Mass for a Full Moon in Summer (2009) and Emma Donoghue's Room (2017). These representative texts by key playwrights use and produce the notions of space in varied ways to critique social, racial and psychological concerns.

Keywords: Theory of space, Theatre of the absurd, Henri Lefebvre, Emma Donoghue, Brian Friel, Michel Tremblay, Henri Bergson, Irish drama 


\section{An Examination of the Use and Production of Space in Brian Friel's Translations (1980), Michel Tremblay's Solemn Mass for a Full Moon in Summer (2009) and Emma Donoghue's Room (2017)}

Rania Khalil

Geographically defined, space is simply a vacant area. Henri Lefebvre in his book The Production of Space (1991) introduces three types of space which he calls the spatial triad by which we can make sense of the complex everyday interactions with space: lived space, conceived space and perceived space. Stuart Elden's reading of Lefebvre elucidates that space may not change, but "our perceptions of [it] does - they become more fine, more subtle, more profound, more differentiated" (182). This theory of space has been used by many theatre scholars to argue that theatre is spatial because it produces space (Morash 2012). This notion of space has been further explored by David Wiles (2003) and Gay McAuley (1999). It has also come under scrutiny by many critics (Massey 2005; Soja 1996; Yi-Fu Tuan 1977; Brooks 1968; Artaud 1968; Jacqout and Bablet 1963; Polieri 1963; and Scherer 1950) among others. Anne Ubersfeld (1999) in her book Reading Theatre breaks space down to: dramatic space, gestural space, and theatre space. Michael Issacharoff in Space and Reference in Drama (1981) reduces them to: theatre space, stage space and dramatic space. To this classification, Rob Kitchin adds in his book Space II (2009) "relational space" (268) which is constructed through social interactions.

In drama, space exists on a semantic level. At the same time, space is more than just what is created by the script and stage directions. Being one of the five irreducible elements of theatre: time, language, body, sound and memory, it also exists on an ontological level. When we think of theatrical space, quite often it is the stage space which is referred to and the analysis barely goes beyond the "scenographic space" (Morash 11) or the "absolute space" (Kitchen 268) of the theatre. Lefebvre's attempt to make sense of the space produced in our everyday life has created important links to the understanding of space in theatre. Within the theory of space, dramatic space is the most elusive type of space to examine in relation to theatre, and hence, it will be given more attention at this point in the discussion. The main forms of dramatic space in theatre are mimetic and diegetic. Mimetic space is represented on the stage and made visible to an audience. Diegetic space is what is referred to through discourse by the characters and is thus verbally communicated; it is not shown on the stage. This fundamental difference is not so much emphasized in modern dramatic works, the interplay between mimetic and diegetic space is skillfully used to create interest and dramatic tension (Issacharoff). Language can also play a crucial role in the manifestation of space as a dramatic work starts first with the script where it is auditory and nonauditory. The dialogue between the characters and the stage directions can both refer to space. Space can additionally 
be conveyed by other means, such as sound, where verbal language is complimented by sound effects - the result is both mimetic and diegetic space are still existent, yet are transmitted in a different way. Modern technology has additionally helped in making a conscious addition to space in the theatre. Images of individual spectators are today highlighted on to large screens to remind audiences of the shared common space and the theatrical experience (Jones). Andy Merrifield, in Thinking Space (2000), refers to space as fluid and organic. In today's modern world, when audiences visit a play's website, they immediately come together despite the geographical distance as an imagined community within the parameters of virtual space (Lefebvre). If no one visits the website, it remains dormant and eventually becomes dead space. Needless to say, the evolution of space in theatre both formally and informally has in turn affected audiences' interactions with the text, the stage and quite often the performers. Theatrical space is summed up into four areas: "theatre location, space within the theatre, scenic space and dramatic space" (Morash and Richards 33). This summary of the notions of space in relation to theatre and drama sets the scene for the examination of the use and production of space in Brian Friel's Translations (1980), Michel Tremblay's Solemn Mass for a Full Moon in Summer (2009), and Room (2017) by Emma Donoghue. The analysis will focus on how the use and production of space through formation and reformulation in each of the dramatic works is used to critique social, racial and psychological trepidations. In each dramatic piece, the utilization and production of space, is illuminating.
Translations by Brian Friel was performed in Derry's Guildhall on 3 September 1980. The play received a standing ovation and was praised in The Irish Times "as a welcome reminder of an essential Irish unity 'across time and territory" (Editorial 9). Representational spaces such as landscapes, which are dense with signification of meaning, have received much attention because of their link to national identity. Brian Friel's Translations (1980), set in Baile Beag, County Donegal in Ireland is about the ability to comprehend and control space. The play revolves around the advent of a detachment of Royal Engineers and British soldiers for a purely administrative task; the naming of Irish places. Meddling in the cultural significance of the landscape space however, proves to have far reaching consequences, for both the local Irish inhabitants of the village and the British soldiers. Space when it is undifferentiated it is space, and when in a more general sense it becomes familiar, it becomes place and has more value. Act Two opens with the view of a map spread across the stage space, Yolland and Owen who are working on the Ordinance Survey, are bent on the stage translating the place names from Gaelic into English. They are "rearranging the exterior space of a nation" (Khalil 9) on a paper landscape. The same visual representation is repeated in Act Three when Maire draws a map of Norfolk where Yolland had drawn it the night before on the sand. Both scenes are a visual illustration of representational space. The familiarity of space in the play is paralleled by a sense of instability. The entangled relationships over cultural and geographical spaces create the tension in the play and give rise to the notion of belonging and not belonging. A visible and invisible representation of "intrusion 
and departure" with a focus on "what it means to belong" (Lojek 18) is signified by the hedge school representation on the stage. Set in a disused hay-shed, the hedge school is where most of the play's action takes place. Hugh, the school master shortly after the play begins, reorganizes his home space into a classroom. The domestic space is reconfigured into a public space. Helen Lojek (2011) explains that "the hedge school space functions alternately and sometimes simultaneously as personal or domestic space and as a public or communal space" (17). The unity of body and soul of a nation is reduced here by Friel into the metaphor of a home. The familiarity of the home/hedge school is contrasted against the ferocious exterior space. The private space of the characters is interrupted by the entrance of two British soldiers: Yolland and Lancey. Friel uses this as a visual image of the intrusion and occupancy of the Irish space by a colonial power. The English soldiers' initiative to forcefully replace Gaelic with English is claimed on the basis of the benefits gained by this replacement in carrying out international business which promises economic success for the little island. Hugh's refusal to use English inside the hedge school by is a demonstration of power and resistance to colonialism. Hugh uses language to demonstrate his relational position to the social space and to the colonial power occupying his space. Translations primarily noted for being a language play, shows both on stage and off stage how "the consciousness of an entire culture is fractured by the transcription of one linguistic landscape" (Kearney 25). Owen (Hugh's son and the translator for the British soldiers) understanding the power in naming places gloats "We name a thing and- bang- it leaps into existence" (45).
Telling his father how to find the priest's house, Owen uses the English names given to the landmarks wondering if Hugh will be able to recognize the "other" new space which had been created by the renaming process- one that is cultured, English, perfect in contrast to that which is Irish and messy. What he is claiming is that words have the power to create and recreate spaces; by renaming a place which is familiar, it becomes unfamiliar and is simply reduced to just a space. Tobair Vree is possibly the most commanding example of the power of manipulating cultural space through renaming. Language is used to impact and occupy space in Translations. Richard Kearney cautions that "Man's being in the world becomes authentic when he ceases to abuse language as a strategic instrument for the manipulation of people" (27) and space. The transformation of Irish topography through the mapping of the landscape and renaming of the exterior spaces "is designed to achieve two objectives: to disassociate the Irish from their past and to control their future" (Rollins 36).

The sense of belonging and not belonging to Irish space is demonstrated in the competition over the land and the controlling of the exterior space. Donegal stands as a contestation of meaning for the different characters in the play: "Lancey sees Donegal as space that needs to be mapped for purposes of civic and military control. Yolland conflates Donegal's landscape with a viable culture that he might be able to join" (20) and Hughes sees it as home, Owen sees it as a symbol of economic success once the place names have been translated into English, Maire and Manus see it as a point of departure. This amalgam of connotations to the 
geographical space is the very reason why the cartographers according to Bernhard Klein (2001) were required "to move beyond a sense of land as a local and social space" and understand that it was "deeply immersed in regional custom, that defies its translation into a set of mathematical data" (Klein 63). The reconfiguration of the town space of Baile Beag leaves the local inhabitants tonguetied and confused; they have been uprooted of their identity and their spatial history is erased. The reconfiguring of the Donegal area is a destruction of the memory, history and identity of the Irish inhabitants. The "geo-spatial mapping" (Khalil 10) on the paper landscape is a powerful act by which the British army reconfigures the island in relation to the exterior world. Helen Lojek explains in her book The Spaces of Irish Drama that Donegal is a '... land, homeland and history' (20). The binary of internal space and external space is heavily signified in Translations.

The exterior space is violent; a British soldier is murdered and Yolland, the youngest of the map-making soldiers at the end of the play disappears mysteriously. At the start of the play, the atmosphere is one of exuberance. Amidst the shabby setting is a love story between a local Gaelic speaking colleen, Maire and Yolland. The irony in this relationship lies in Yolland's words in Act II when he makes up his mind about the space he will occupy: "I thought - I knew - perhaps I could live here ... Where's the poteen?" (Friel 416) and indeed he never leaves. Violence in the exterior space such as the mysterious disappearance of Yolland, burning farms and killing animals takes place off stage. Mathew Johnson (1996) debates this violent act of suspected murder by explaining that the cultural significance of the land had been replaced with "utilitarian" (114) indicators which formed a gap between the land as a geographical space and what it signifies culturally and socially to the local people. The severity of the acts as Friel implies, lies in the tampering with the place names. Separated by a window, the interior and the exterior space in Translations is presented as two separate worlds; the window shields the local school master and the others from the violent exterior space which ironically, is full of anarchy. The stage space in Translations is a continuous opposition between the interior and the exterior. The home representation serves as space for a range of social relations all of which lack unity. The internal space stands for a dysfunctional family and possibly a whole nation. Significantly, the relation of the local inhabitants to the landscape space is inherent in this anarchy, it is their world, their space and only they know how to navigate that landscape. According to Helen H. Lojek (2011), 'The Irish know their literal place very differently than the map does, and they understand their figurative place very differently than the English do" (35). Hugh, is someone who could blind-folded find his way through the rural space, he describes marching twenty-three miles "across the fresh green land" (Friel 81) when he went to battle in 1798. By the end of the play, the once familiar rural places in County Donegal are transformed into what Lefebvre (1974) calls an "empty abstraction" (1) which require a new spatial understanding of the Irish landscape in order to survive.

Friel's Translations extensively explored for its many themes, links "landscape and language to ideological issues associated 
with national identity" (Llewellyn-Jones 23). Most recently, it has been analyzed for its social transformation of representational space, the use of space and the production of "other" space. County Donegal is a place in transition that is reformulated into a new space that will be thrust forward into the twentieth century. The play today still raises one of the most sought after questions: is space an object or a social product? Friel's Translations leaves audiences to answer this question according to their own definition of time, culture and place.

Originally written in 1996, Solemn Mass for a Full Moon in Summer (2009) by Michel Tremblay, was translated from Québécois into English by Irish playwright Bryan Delaney. Delaney's translation of the play was applauded for its remarkable precision and was produced by Rough Magic Theatre Company in March 2009 in Dublin. Designed around eleven residents in a Montreal apartment building, the play's action takes place on their balconies. In search for peace of mind, their prayers, vocalized from each of the six terraces unite as they chant their "imprecations to the full moon" (Khalil 18). Monologues and short scenes are weaved together by Tremblay to give way to six vignettes, the play is structured by the passage of the moon into microdramas. The interplay between the stage space and gestural space in Tremblay's play is most illuminating. Paul O'Mahony, in constructing the stage space of the play, shifts from the horizontal layout to the vertical. He uses "minimal scenic elements" against a "vertical cosmos schematic" (Mendes \& Tulloch 4 parag.10). The significance of the vertical scenic space is heightened by the absence of the moon and complemented by the full presence of its light. We never fully see the moon " $\ldots$ only its light, from an initial red glow over the stage, to a dazzling, monochrome white light in the sky, crossing the zenith, and finally as fingers of a deeper red, seeping through shadows, leaving the set in darkness" (Morash 8). Light, quite commonly used to structure time, is equally valuable in creating space. It creates what Andy Merrifield in Thinking Space (2000) calls "ontogenetic space" (171). The atmosphere in Solemn Mass is to a great extent stagnant; characters do not evolve or undergo any theatrical transformations and are confined to the minimal space of their balconies. Yet, the space in this dramatic work is fluid, alive and present. Solemn Mass as a dramatic performance creates a different form of space. In two instances, the empty area between the actors and the audience, is transformed into theatrical space: two men come out on to the area in front of the vertical apartment building and occupy the space in front of the scenic space; the same space the second time, is occupied by a young couple Isabelle and Yannick who dance to celebrate their first love. The empty space in front of the audience becomes alive. These two epiphanies, which bookend the play, hold very little action in between. Chris Morash in Making Space: Towards a Spatial Theory of Irish Theatre (2012) explains that no transformation happens to the characters in Solemn Mass “... and in this regard the confining, atomising space of the balconies is the play's defining image. ... the space is utterly transformed in those two brief moments" (10). According to Anne Ubersfeld, Solemn Mass by presenting every day space, it "constructs space that is not only structured, but in which structures become signifying" (102). The play initially inspired by the 
choral of Christian mass, produces a unity of space through the sound of prayer as each of the character's voices rises and separates with absolute precision towards the full moon in hope of evoking inner peace. The spatial parameters of the scenic space and the audiences' communal theatrical experience are bound by the absolute space of the theatre. Scrutinizing the minimal space on which the play is founded intensifies our awareness of the freedom of space and the threats that come with this openness. Liminal space as it is configured on the Tremblay's stage suggests to the occupants of the six apartments that their salvation and inner peace rests in accepting their restricted space. More importantly, Solemn Mass "opens up something closer to the idea of a diasporic space than to the more conventional forms of representational fictional space" (Morash 15) when the audience involuntarily respond with "And also with you" as the mock religious mass on the stage comes to an end. Knowing that audiences elsewhere around the world would have reacted similarly to the same lines chanted on the stage, is what Morash (2012) and Lefebvre (1974) consider to be the formulation of "conceptual space" (188). It is the outcome of the interrelatedness of what Lefebvre has labeled "the perceived, the conceived and the lived" (Morash 14) space.

Extending on the notion of interacting with imagined audiences, technology has unified abstract spaces through the use of virtual space. Rough Magic Theatre Company by creating a website to promote for the play Solemn Mass brought to life instantly another type of conceptual space. The social media links and the website for the play allowed audiences to interact through remote and diversified abstract space. This new form of absolute space, only becomes present space and alive when accessed, because "a website is poised between the prospective of reawakening and the acknowledgment that it is dead" (Khalil 21). Accessing and interacting with conceptual space from a diversity of physical and geographical spaces has given the spatial parameters of the theatre a global dimension. Tremblay's play provides an excellent example of the different kinds of space produced by theatre ranging from the absolute space of the theatre space, scenic space, gestural space, to conceptual space and virtual space. Structured by the light of a full moon and the rituals of pre-Christian Mass, the varied notions of space in Solemn Mass are skillfully used to give voice to the "guilt, grief and heartbreak" (Rough Magic Theatre Company) of eleven people on their balconies in a "vertical cosmos schematic" (Mendes \& Tulloch 4 parag. 9).

One of the bestselling narratives in post-Celtic Tiger Ireland is Room (2017) by Emma Donoghue. The play was produced by the Abbey Theatre Dublin in July 2017 and received a number of awards. Donoghue's two act stage play, revolves around $\mathrm{Ma}$ and Jack's experiences in and out of an 11x11 backyard shed where they are held captive by Old Nick their abductor. The backdrop against which the play is set, reflects the social and economic changes which resulted in Ireland from the economic boom known in the 1990s as the Celtic Tiger. The liminal space of the play's setting and the minimalist design of the stage space contrast against key critical issues of racial tensions, social pressures and psychological strains. The play also draws strong parallels in its use and 
production of space to Brian Friel's Dancing at Lughnasa; Philadelphia Here I Come!; Samuel Beckett's Waiting for Godot; and Harold Pinter's The Room.

The play in two acts, takes place across the span of seven years in an $11 \times 11$ foot backyard shed. The second Act of the play, takes place in the outside world. The play echoes absurdist plays with its two characters trapped in a space waiting to make sense of the world, and their human existence. The similarity lies in the "articulation of boredom"... [as it] "becomes the most meaningful activity of the day [where both] characters are isolated from an outside world... in an urban dwelling... sharing a rhetoric of despair that leaves [the play] unresolved other than in a general consensus to continue, to survive. For what else is there?" (Bull 50). The reality which Ma and Jack constitute for themselves in Room stems from referencing the world of TV and fairytales to create a warm and loving home. The liminal confining space, ironically is a "saving refuge"(Cover 118).

The complexity of space in Donoghue's Room is better understood through Henri Lefebvre's notions of space shared earlier. Lefebvre in his book The Production of Space having divided the spatial triad into lived space, conceived space and perceived space, defines them as "the three moments of social space" (40). Donoghue in Room, depends on Lefebvre's further association of space with the notion that its definition and significance changes based on the perspective of the individual. Additionally, her application of Edward Casey's phenomenological theory of place is also evident in the "way in which place gathers the animate and inanimate" (Russell 198) in the first Act of the play. These two concepts aid in dismantling the intricate connections of space in the play which shape the lives of Jack and Ma.

Mimetic space in this play takes centre stage, and is visible to the audience. The setting of Room on the Abbey Theatre stage is filled with Jack's drawings projected by the video display redefining the boundaries of his own world inside the theatre's absolute space. Space in Room is also "divinely ordered (... cosmological)" (Mendes \& Tulloch 1) as well as psychological. The stage space is shared by two versions of Jack: Little Jack, a child and Big Jack, which is played by an adult delivering the five year old's inner thoughts in a monologue. The visual definition of the theatrical space of the stage is used to give the audience a glimpse of the psychological inner space of the character (Vanstone 42).

Theatre critics see Jack as a representation of two of Brian Friel's characters. The effective stage technique of showing two versions of the same character was used by Brian Friel in Philadelphia, Here I Come! (1964). Gar O'Donnell, like Jack in Room, is represented on the stage as two characters: Gar Public and Gar Private. Friel explains in the play's stage directions that Gar Public never sees Gar Private or looks at him; he is his alter ego, the id. The two characters, played by two different actors share the same scenic space. Gar Private "vocalizes personal fantasies and private desires" in utter eloquence (Harrington 145). Public Gar on the other hand, struggles to resolve the "longstanding impasse with his father" (145) through a childhood memory of a fishing trip; he is stuck in the past. Stage directions indicate that he is two views of the same man. The opening scene of the play shows Public 
Gar on the stage and is joined by Gar Private as soon as Madge the housekeeper exists:

PUBLIC: It's all over.

PRIVATE: (off, in echo-chamber voice): And it's all about to begin. It's all over.

PUBLIC: (now on) Just think, Gar.

PUBLIC: Think ...

PRIVATE: Think ... UP in that big bugger of a jet, with its snout pointing straight for the States, and its tail belching smoke over Ireland; and you sitting up at the front (PUBLIC acts this) with your competent fingers poised over the controls; and then away down below in the Atlantic you see a bloody bugger of an Irish boat out fishing for bloody pollock and-

Public nose-dives, engines screaming, machine guns stuttering. (Friel, Philadelphia 31).

The split duality of Gar's personae as Peter Harris (2010) puts it exposes the agony of a character who is trapped between a tormented past and an unknown future. Similarly, Richard Pine in Brian Friel and Ireland's Drama (1990) argues that the real innovation in this play is the dramatizing of the duality in the personae of the main character as he leaves a past of predictability in Ireland for a future of uncertainty in America. Chris Murray, in evaluating the significance of this stage technique, highlights that the use of familiar characters and traditional material, allowed Friel to focus on depicting the character's sense of alienation, "uncertainty and agnosticism" (169). The other Friel character, to which Jack is compared, is Michael Mundy from Dancing at Lughnasa (1990). Michael as an adult, narrates his memories when he was a seven year old boy. Michael the child is never seen on the stage although the other characters address the invisible boy and it is the adult Michael that answers. Like Jack in Room and Gar Private in Philadelphia Here I Come!, Michael in Dancing at Lughnasa "establishes a dialectic between [the] conscious and [the] unconscious" (Fussco 109). This similarity is further complemented by the limited actions of listening to music and dancing. Jack however, although similar on many levels to Friel's characters, is neither an adult reflecting on his memories like Michael in Lughnasa nor is he, because the role is played by an adult, like Gar in Philadelphia; "he's never really quite one or the other"... "there is not a huge schism between his public and private self" (Lonergan). However, all three characters, attempt to "escape the crushing otherness of their existence" (Fussco 117) whether physically or through a mental state. Through this same dramatic technique, Donoghue like Friel, reverts to the traditional use of the Irish storyteller "seanachie" (111).

The third-person medium of the play Room, is staged on a revolving shabby physical liminal space which is designed with architectural precision that communicates the intimidating prospects of the play. The term liminal became widespread through Victor Turner (19201983) but originated from Arnold Van Gennep's concept of liminality in anthropology in 1909. In Latin, "limen" means threshold. It is also defined as the point between one space and the next point of space (La Shure). The liminality of the set design in Room alternates the audiences' perception between the psychological and the physical through vertical and horizontal cosmologies giving 
us a sense of the interior life of the young boy. Light is also used to show the interplay between interior and exterior space. Further manipulation of space takes place when Big Jack directly addresses the audience; the space between the stage and the audience transforms from a non-space to theatrical space where the audience become part of the child's inner world. This same theatrical technique was used by Michel Tremblay in Solemn Mass to accentuate the spatiality of the stage set and interact with the audience.

The liminality of the $11 \times 11$ foot shed in Room intensifies the displacement of Ma and Jack and heightens our awareness of their status as prisoners. Old Nick's relationship to $\mathrm{Ma}$ is a sort of darkly parodic marriage. His sexual fantasy has ironically become a burden as he struggles to provide for Ma and Jack after getting laid off from work. The power he enjoyed over his hostages is diminished and what we see is "masculinity in crisis" (Hansen et al. 43). During the rise of the Celtic Tiger, Irish masculinity was defined by the acquisition and display of wealth, through which identity was constructed and affirmed (Woods 29). The play, indirectly interrogates the "cultural tropes of masculinity and femininity in the recession" (O’Neill 64) as well as critiques the structures of inequality and gender construction. It is the vulnerable in society such as women, children, and single mother families that mostly suffered the repercussions of the Celtic Boom. Ma and Jack's existence is threatened by their social and economic dependency on Old Nick. Heteropatriarchy (McNeil et al. 45) is configured in the dominance exercised by Old Nick over Ma and Jack as two vulnerable black members of society. The forced confinement bears resemblance to a colonial setting. The black body, has always endured the most degradation as an icon for the uncivilized compared to the white body, iconic for freedom and the civilized. The black female body, in turn, has always been viewed as "impure, savage, and embodied evil" (Pro Sobopha 120). In Act I in Room, black female dominance over the white man is exemplified in Ma's words "Come to bed.... Come to bed. Please! She brings him [Old Nick] to Bed" (Donoghue 20). Every physical encounter is an embrace of freedom, a triumph for the black body and an illustration of a crumbling white supremacy. It is difficult not to see this scene as a reverse of the roles of Othello and Desdemona.

Further to this, one cannot but make parallel connections between the absurdity in Room and the absurdity in Samuel Beckett's Waiting for Godot (1954). Angela Hotaling points to this similarity: "The exact location is unknown and it appears that the characters are placed in some 'distant region' that could be anywhere" (1). Similarly, in Harold Pinter's The Room (1957), the room space is the only structured element in the unstructured world around the female characters Ma and Rose. Both characters are uncertain of the location of their living space. Significantly, neither one can determine where they stand in the void outside the concrete walls. The association between this feeling of alienation and sense of protection is extended in the suggestion that Old Nick, Ma and Jack's captor, instills both fear and relief. After Jack sleeps, Old Nick brings groceries, clothes and Sunday treats. The prolonged confinement in the shed has shaped the three characters into disoriented people. To Jack, Room is the whole world: "Room 
wasn't too small, it went all the way in every direction. Everything was in its place and every day was just long enough for everything we had to do" (Donoghue 46). Jack's innocent perception of Room reflects Lefebvre's point of view that space is defined by the onlooker and changes with our shifting perspectives. The notion of space in Room shifts from the physical to the abstract.

Donoghue's procreated Becktian characters who question their belonging; Big Jack contemplates his existence: "When I look up through Skylight there's Outer Space with all the Stars and Planets and Moon and Sun spinning spinning spinning around us. And then way farther up there's Heaven, where I came from when I was the tiniest little speck" (Donoghue 1). This connection between the child and the heavens can easily pass for a religious seeing. The stage plan follows the divine order of Heaven, Earth and Hell. Heaven is signified by the skylight roof, the main stage is Earth and sometimes Hell. Ma and Jack are in hell which ironically, is their sanctuary from the mad world outside. On a more eschewed level of interpretation, Room can be symbolically interpreted as a womb. Emma Donoghue points out that "We all start in a womb and then enter a wider world... which continues to open out further as the person's social milieu expands. The story of ROOM makes this literal - and frightening - because it happens all in one go, in a context of terror" (Donoghue, Emma. Personal Interview. 25 January 2018). Labeled by the media as "Bonsai Boy" (Donoghue44), Jack's desire to remain in Room is metaphorical for a return to the womb for its protectiveness and limited activity. The metaphor is extended when Jack learns that he had a still born sister who is buried in the garden outside the shed. The dead child leaves its mother's womb, only to be buried in mother earth. At the same time, Ma's giving birth astride a graveyard to a still born reminds us of Pozzo's meditative speech in Samuel Beckett's Waiting for Godot: "... They give birth astride of a grave, the light gleams an instant, then it's night once more" (Beckett 83). When Old Nick cuts off the power on Ma and Jack, the room is completely dark, just like the womb. It is also a return to a primitive existence. Holding together these two interpretations is Donoghue's explanation: "I wanted to almost think of them as a tribe of two," (National Public Radio NPR). Ma and Jack completely detached from the outside world plunge back in time where the conditions created are "analogous to that of a [cave] existence: darkness, [and] the absence of excitement....an intermediary state of nonlife and non-death" (Smathakarnagsorakij 40-41). These conditions once again bear a striking resemblance to Beckett's Waiting for Godot. Donoghue characters as existentialists where life for them is meaningless and arbitrary outside the shed. Amidst such absurdity one can only think: "Is this another version of Waiting for Godot?" (Smathakarnagsorakij 58).

The spatial metaphors in Room take on many forms and are heavily rooted in metaphorical imagery that relate to the psyche. One of the most valued scenes is when Jack is inside the wardrobe. Through the limited absolute space he inhabits, Jack learns to "shape himself to new and strange landscapes" (Sullivan). Donoghue sheds more light on this explaining: "I love the moments in the ROOM production when the set revolves and we're with Jack in the tiny wardrobe, only 
obscurely seeing what's going on with $\mathrm{Ma}$ and Old Nick" (Donoghue, Emma. Personal Interview. 25 January 2018).

Gaston Bachelard in The Poetics of Space (1969) discusses the "intimate value of inside space" (3). He elaborates on the metaphors of intimacy by referring to Henri Bergson's popular “drawer metaphor" (75). According to Bergson, the brain is likened to a keep-sake box, and concepts are like drawers that need to be compartmentalized. The drawer metaphor however has been criticized for its inability to "unite exterior realities with intimate reality" (78). On the other hand, "wardrobes with their shelves, desks with drawers, and chests with their false bottoms" (78) on a philosophical level, connote a "secret psychological life" (Bachelard 78). This Bergsonian metaphor is signified in Jack's wardrobe. Within this context, the inner space of Jack's wardrobe is an "intimate space" and also a "center of order" (79) set against a backdrop of disorder. The significance of the wardrobe is highly psychological in its ability to communicate to the audience the intricate connection between protecting a child, the tumult memories of the child, the child's own sense of secrecy, and the strong need for a focal point of order amidst chaos. In reverse meaning, the wardrobe space is where precious things are kept. Ma protects Jack by making him stay in the wardrobe during Old Nick's nocturnal visits. There is no lock on the piece of furniture, and significantly, there is no psychological threshold to shelter the boy from becoming a "freak" (Donoghue 19). The wardrobe space unites the animate with the inanimate which extends the image to that of the protectiveness of the home. It is the last space he occupies before he is cast out into the world and its vast exterior space. Jack's escape in Act II to the outside world is a "divisive point in his spatiotemporal understanding" (Khalil 32). He struggles with the new reality in which he exists: "I don't want to be in the world" (Donoghue 44). After years of spatial confinement and bewildered by the spatiality of the outside world, Jack continues to resort to the TV. Metaphorically he joins through TV a mass of imagined audiences to construct his very own conceptual space. Adjusting to the norm is overwhelming for both $\mathrm{Ma}$ and Jack:

He and MA put on sunhats and sunglasses and start to go through the door ... LITTLE JACK panics and runs back indoors.

MA: What's wrong?

LITTLE JACK: Too much.

MA: Too much what?

LITTLE JACK: Too much everything. (Donoghue 56)

As he makes the passage from one space to another, Jack faces two directions: "towards a home that has been lost, and to a place that is not yet home" (Ahmed 10). Like Brian Friel's Private and Public Gar, he leaves behind a space of certainty for a future space of uncertainty. Jack decides to go back to Room, "Just to visit. ...Plant's thirsty. And Labyrinth and Sockdog and Eggsnake and Wonky Chair and Meltedy Spoon, they must be lonely. Nobody's singing them songs or telling them stories" (Donoghue 74). Arnold Wesker in his article titled One Room Living (1962) states that to have never stirred beyond one room is lunacy, mean and a waste of one's life. Having moved from Room in Act I into his grandparents' home in Act II, Jack displays signs of psychotic despair: "We've been in the world for 
seventeen days and a quarter and I still never know what's going to hurt. Needles, and ... tables banging into me, ... and doors trying to chop my fingers off. ... Ma's stressed all the time and I'm not to bother her, I have to give her space. I'm scared to go outside" (Donoghue 59).

Overall, it can be said that in Room, space is an interplay between the fictitious and the real, the physical and the psychological. It is also a product of the dynamics of social relations. Social, racial and psychological concerns are examined through the formulation and reformulation of space. Additionally, the liminal space of the revolving stage is carefully exploited to dramatize Jack's dual personae, a stage technique that revives the traditional Irish storyteller and mimics Brian Friel's style in two of his most noted plays: Philadelphia Here I Come! and Dancing at Lughnasa. Non-physical space is also brilliantly conveyed by Donoghue through a vertical cosmos sky-roof, TV and the Bergsonian space metaphor. Room, demonstrates Donoghue's sound understanding of theatre history as well as the use and production of space.
Diverse in content and form, the three plays selected for analysis, effectively employ theatre elements to explore the varied notions of space on a semantic and on an ontological level. In all three plays, space is a constant element, but as Henri Lefebvre and Anne Ubersfeld argue: it is produced and reproduced to create new realities and new spaces. There is no homogeneous space. Friel's Translations is about controlling space and the inevitability of change through the use of representational space; Michel Tremblay's Solemn Mass manipulates space to restore the intimacy between actors and audiences both physically and virtually, while Donoghue's Room cleverly demonstrates multiple stage techniques for using and producing space on the stage and off the stage.

\section{Acknowledgment}

I wish to thank Emma Donoghue for the interview and to thank her publisher Oberon Books for providing a free copy of the stage play for the purpose of this research. I also wish to thank the reviewers for their constructive feedback and guidance. 


\section{Works Cited}

Ahmed, Sara. Queer Phenomenology:Orientation, Objects, Others. Durham: Duke UP, 2006.

Artaud, Antonin. Le Theatre et son double. Paris: Gallimard Collection Idees, 1968.

- The Jet of Blood in Modern French Theatre. New York: George Wellwarth, 1966.

Bachelard, Gaston. The Poetics of Space. Boston: Beacon Press Books, 1969.

Beckett, Samuel. The Complete Dramatic Works. London: Faber and Faber, 1986.

- Waiting for Godot. New York: Grove Press, 1954.

Berlant, Lauren and Michael Warner. "What Does Queer Theory Teach Us About X?" Publications of the Modern Language Association of America 110.3 (1995): 343349.

Brooks, Peter. The Empty Space. New York: Touchstone, 1968.

Bull, John. Stage Right: Crisis and Recovery in British Contemporary Mainstream Theatre. New York: Macmillan Education, 1994.

Cover, Rob. Queer Youth Suicide, Culture and Identity: Unliveable Lives? Burlington : Routledge, 2011.

Donoghue, Emma. Making space for 'Room' on the Theatre Stage: Interview with Emma Donoghue Rania M R Khalil. 25 January 2018.

—. Room. London: Picador, 2010.

Editorial. "Opening Night." The Irish TImes 22 August 1980: 9.

Elden, Stuart. Understanding Henri Lefebvre : theory and the possible. . London: Continuum, 2004.

Friel, Brian. Dancing at Lughnasa. Farrar : Straus and Giroux, 1990.

—. Philadelphia, Here I Come! Selected Plays. By Brian Friel. London: Faber and Faber, 1984.

- Selected Plays Brian Friel. Washington: The Catholic University of America Press, 1986.

- Translations. London: Faber and Faber, 1981.

Fu Tuan, Yi. Space and Place. Minneapolis: University of Minnesota Press, 1977.

Fussco, Cassandra. "The Dancer or the Dance: A Critical Analysis of Brian Friel's Dancing at Lughnasa." Etudes Irlandaises 21.1 (1996): 109-126. 
Hansen, Heidi, et al. Masculinity in Crisis. Project. Trekroner, Denmark: Roskilde University- International Basic Studies in Humanities 3.1.1., 2012.

"Brian Friel: Erin on Broadway." Harrington, John. The Irish Play on the New York Stage 1874-1966. The University Press of Kentucky, 1997. 146-165.

Harris, Peter. "UNIVERSAL OR PROVINCIAL? : EARLY RECEPTION OF BRIAN FRIEL'S PHILADELPHIA, HERE I COME!" Ilha do Desterro 58 (2010): 23-51.

Hotaling, Angela. "Camus and the Absurdity of Existence in Waiting for Godot. SUNY Oneonta (Oneonta,." 29 February 2016. Docit.Tips. 5 September 2018 $<$ https://docit.tips/download/camus-and-godot-existentialism-albert-camus_pdf $>$.

Issacharoff, Michael. "Space and Reference in Drama." Poetics Today - Drama, Theatre, Performance: A Semiotic Perspective 2.3 (1981): 211-224.

Jacquot, Jean and Denis Bablet, Le Lieu Theatral dans la societe moderne . Paris : Editions du CNRS, 1963.

Jones, Lloyd Llewellyn. "Understanding Theatre Space." June 2002. Classical Receptions in Drama and Poetry in English from c.1970. 27 August 2018 $<$ http://www.open.ac.uk/arts/research/greekplays/publications/essays/llewellynjones-understanding-theatre-space $>$.

Kearney, Richard. "Language Play: Brian Friel and Ireland's Verbal Theatre." Studies: An Irish Quarterly Review 72.285 (1983): 20-56.

Khalil, Rania. "The Irish Theatre As Imaginative Space: A Vehicle and Venue for the Reconstruction of the Irish Identity." Global Journal of Arts, Humanities and Social Sciences 5.10 (2017): 24-34.

Kitchen, Rob. "Space II." R. Kitchen \& N. Thrift The International Encyclopedia of Human Geography. Mynooth: Elsevier, 2009. 268-275.

Klein, Bernhard. Maps and the Writing of Space in Early Modern England and Ireland. New York: Palgrave Macmillan, 2001.

La Shure, Charles. Liminality - The Space in Between. 18 October 2005. 31 August 2018 $<$ http://www.liminality.org/about/whatisliminality/>.

Lefebvre, Henri. Lefebvre, H. (1991) The production of space, Oxford: Blackwell. Oxford: Blackwell, 1991.

Llewellyn-Jones, Margaret. Contemporary Irish Drama and Cultural Identity. Intellect, 2002.

Lojek, Helen. The Spaces of Irish Drama. New York: Palgrave Macmillan, 2011.

Lonergan, Patrick. Scenes from the Bigger Picture: Room by Emma Donoghue at the Abbey. 27 June 2017. 8 March $2018<$ https://patricklonergan.wordpress.com>.

Massey, Doreen. for Space. London: Sage Publications, 2005. 
McAuley, Gay. Space in Performance: Making Meaning in the Theatre. Ann Arbor:: University of Michigan Press, 1999.

McNeil, Elizabeth, James Wermers and Joshua Lunn. Mapping Queer Space(s) of Praxis and Pedagogy. Phoenix, Arizona: Palgrave McMillan, 2018.

Mendes, Tanit and Janet Tulloch. "Set Design as Cosmic Metaphor:Religious Seeing and Theatre Space." 2006. Theatre Research in Canada. 19 March 2018 $<$ https://journals.lib.unb.ca/index.php/tric/article/view/11097/11774>.

Merriam Webster Incorporated. Merriam Webster Dictionary. 2018. 15 March 2018 $<$ https://www.merriam-webster.com/dictionary/queer $>$.

Merrifield, Andy. Thinking Space. Ed. M. Crang and N. Thrift. London: Routledge, 2000.

Morash, Chris. "Making Space: Towards a Spatial Theory of Irish Theatre." Grene, N. and P. Lonergran. Irish Drama: Local and Global Perspectives. Dublin: Carysfort Press, 2012. 7-21.

National Public Radio NPR. In Donoghue's 'Room,' A Child's World Of His Own National Public Radio. 27 September 2010. 2 March 2018 $<$ https://www.npr.org/2010/09/27/130143360/in-donoghue-s-room-a-child-sworld-of-his-own>.

O'Neill, Margaret. "Transformative Tales for Recessionary Times: Emma Donoghue's Room and Marian Keyes' The Brightest Star in the Sky." Lit: Literature Interpretation Theory 28.1 (2017): 55-74.

Pine, Richard. "Brian Friel and Ireland's Drama." Colby Quarterly 27.4 (1991): 190-201.

Pinter, Harold. The Room and The Dumb Waiter. London: Methuen, 1960.

Polieri, Jacques. "L'Image a 360 et L'espace scenique nouvea." Jacquot, , Jean and Denis Bablet, DENIS. Le Lieu theatral dans la societe' moderne. Paris: CNRS, 1963. 131-148.

Pro Sobopha, Mgcineni. "The Body:gender and the politics of representation." 19.63 (2005): 120.

Rollins, Ronald. "Friel's Translations: The Ritual of Naming." The Canadian Journal of Irish Studies 11.1 (1985): 35-43.

Rough Magic Theatre Company. 2018. 4 September 2018 $<\mathrm{http}$ ://www.roughmagic.ie/archive/solemn-mass-for-a-full-moon-in-summer/>.

Russell, Richard. Modernity, Community and Place in Brian Friel's Drama. Syracuse University Press, 2013.

Scherer, Jacques. La Dramaturgie Classique en France. Paris: Niz, 1950.

Smathakarnagsorakij, Nootchanart. "Body and Space for Evasion in the Theatre of Samuel Beckett." MANUSYA: Journal of Humanities Regular 14.1 (2011): 39-62. 
Soja, Edward. Thirdspace: Journeys to Los Angeles and Other Real and Imagined Places. Oxford: Blackwell, 1996.

Sullivan, Moynagh. Creativity and Play as Social Transformers in Emma Donoghue's Room. 18 June 2014. TEDx Fulbright Dublin. 18 October 2017 $<\mathrm{https}: / /$ www.youtube.com/watch?v=_rJ05xntAPA $>$.

The Open University is incorporated by Royal Charter (RC 000391). Lloyd LlewellynJones: Understanding Theatre Space. 2018. The Open University. 19 March 2018 $<$ http://www.open.ac.uk/arts/research/greekplays/publications/essays/llewellynjones-understanding-theatre-space $>$.

Ubersfeld, Anne. L'Ecole du Spectateur. Paris, 1981.

- Reading Theatre. Ed. Paul Perron and Patrick Debbeche. Trans. Frank Collins. Toronto: University of Toronto Press, 1999.

Vanstone, Suzanne. "'Girard Welcomes Siegfried." Prelude: The Voice of the Canadian Opera Company." Prelude: The Voice of the Canadian Opera Company (2004): 42-44.

Wesker, Arnold. "One Room Living." New Theatre Magazine 3.2 (1962).

Wiles, David. A Short History of Western Performance Space A Short History of Western Performance Space. Cambridge: Cambridge University Press, 2003.

Woods, Jeannine. "'Transformations of Genered Identity in Ireland."." Masculinity and Irish Popular Culture: Tiger's Tales. Ed. Conn Holohan and Tony Tracy. New York: Palgrave Macmillan, 2014. 27-41. 